\title{
AZ EGÉSZSÉG, A KÖRNYEZET ÉS AZ ÉTKEZÉS KAPCSOLATA - SZAKIRODALMI ÁTTEKINTÉS
}

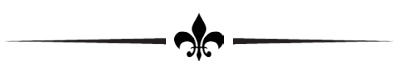

ANALYSIS OF THE HEALTH - ENVIRONMENT - NUTRITION NEXUS: A REVIEW

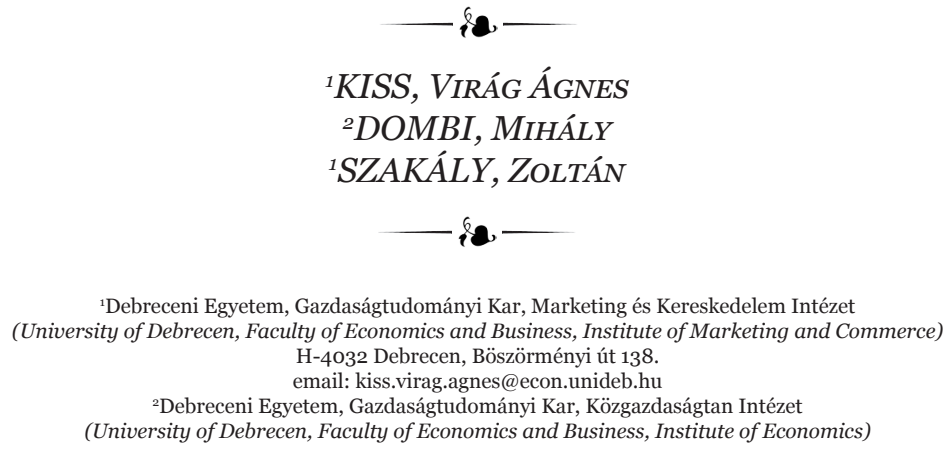

\&

The fastest improvement of the wealth and quality of life was witnessed in last decades by the humanity globally. Economic and social development, however, influenced the state and processes of the natural environment at the same time significantly. Food supply is one of the major interfaces between the society and the natural resources, as we highlight in our literature review; approximately one-third of the resource use and pollution is originated in nutritional needs. Also, health effects of western diet are remarkable. Consequently, debate on 'healthy diet' and 'environmentally friendly' food supply chain became complementary and reinforcing topics recently, at least in the scientific communication.

KuLCSSZAVAK: környezet, környezeti hatások, egészség, egészségtudatosság, élelmiszer élelmiszerfogyasztás, fenntarthatóság

JEL-KódoK (JEL CODES): F64, I12, O13, Q4, Q5

DOI: https://doi.org/10.20494/TM/6/1/1

\section{BEVEZETÉS - INTRODUCTION}

Az elmúlt hetven év az emberiség számára történelme talán leggyorsabb fejlődési szakaszát jelentette. Az emberek széles rétegei tudták maguk mögött hagyni a szegénység és éhezés kínzó kötelékeit, miközben a kommunikáció, kereskedelem és közlekedés terén végbement robbanásszerü technológiai előrelépések megnyitották az utat a fogyasztás, a szabadság és a tudomány demokratikus térnyerése előtt. En-
KEYWORDS: environment, environmental impact, health, health awareness, food, food consumption, sustainability nek a folyamatnak viszont kétségtelenül azonosíthatók az árnyoldalai is: paradox módon egyre szélesedő ismereteink és tudásunk ellenére egyre kétségesebb az, hogy hagyományos kulturális értékeink, egészségi állapotunk és a természeti környezetünk hosszú távon javulni tudnak.

Szakirodalmi áttekintésünkben annak a lehetőségét vizsgáljuk, hogy a hosszú távú gazdasági fejlődés fentebb bemutatott „káros mellékhatásai” közül lehetséges-e érdemben többet 
együttesen „kezelni”. A fenntartható fejlődéssel - vagy újabban körkörös (cirkuláris) gazdasággal - foglalkozó szakirodalom egyre inkább összpontosít a különböző ökológiai és társadalmi problémák közötti kapcsolatra az igen öszszetett fenntarthatósági kérdésekre adott hibás környezetpolitikai reakciók elkerülése érdekében. Cikkünkben az egyik legnagyobb jelentőségü ilyen kapcsolatrendszer bemutatására teszünk kísérletet, ez az élelmiszerfogyasztás, és annak a természeti erőforrásokkal, valamint az egészségmegőrzéssel fennálló kölcsönhatásai. A fogalmakat önmagukban, majd a szakirodalomban fellelhető, őket összekapcsoló modellek mentén mutatjuk be.

Az emberi társadalom fogyasztásának tárgyát jelentő termékek és szolgáltatások közül három csoport emelhető ki környezeti hatásuk szempontjából: a közlekedés, a háztartási kiadások és az élelmiszer. A környezetterhelést mérő indikátorok segítségével egyértelmüen megállapítható (pl. LCA, ökológiai lábnyom), hogy az élelmiszer-ellátás a rendelkezésre álló természeti erőforrások közel egy-harmadát veszi igénybe. Az élelmiszerek és italok fogyasztása globálisan 31\%-ban járul hozzá a klímaváltozáshoz (HERTWICH, 2011), környezeti hatásai általában az összes fogyasztás 20-30\%-nak felelnek meg, és ennek további növekedése várható (TUKKER et al., 2011). Étrendünk az állati termékek és az élelmiszer-veszteség és -hulladék mennyiségének visszafogásával mozdítható el az alacsonyabb környezetterhelés felé, mely változások egyébként az egészségügyi ajánlásokkal is összecsengenek (WESTHOEK et al., 2014).

A magasabb energiasűrüségű élelmiszerek (zsírok, cukor) fogyasztásának növekedésén keresztül a hosszú távú gazdasági fejlődés társadalmi szinten az élelmezési helyzetben javulást, azonban annak szerkezetében káros változásokat is okoz (RUINI et al., 2015). Az egészségtelenebb, magasabb energiatartalmú és kevésbé változatos étrend könnyebben elérhetővé vált az elmúlt évtizedekben a jövedelem erőteljes növekedésével párhuzamosan, például a felhasznált fehérjék mennyisége jóval magasabb az élelmiszerfogyasztásban a fejlett országokban, ez utóbbi az ezredfordulón tízszerese volt a fejlődő államokénak (JOHNSTON et al., 2014).
A magyar lakosság életmódjának átalakítása mára társadalmi és gazdasági szempontból is égetően szükségessé vált. A lakosság egészségügyi állapota nem megfelelő, ezt bizonyítják az olyan lesújtó tények, mint például hogy hazánkban a negyedik legmagasabb az öt évesnél idősebbek körében a túlsúlyosak és kórosan elhízottak aránya a világon (OECD, 2017), illetve egy 2013-as felmérés szerint az Európai Unióban nálunk a legmagasabb a korai halálozások száma, mely az akkori uniós átlag duplája volt (OECD/EU, 2016). Az egészségügyi kiadások megterhelik a központi költségvetést, a munkaerő, mint termelési tényező pedig egyre inkább bizonyul szúkös erőforrásnak, mindemellett pedig a dolgozók egészségügyi állapotától egyáltalán nem független munkatermelékenység hoszszú évek óta gyakorlatilag stagnál.

Tanulmányunk első fejezete a környezettudatosság, míg a második az egészségfogalom és az egészségmodellek alapismereteinek rövid ismertetését kínálja. Ezután a nemzetközi és a hazai élelmiszerfogyasztási trendeket mutatjuk be tömören, végül pedig az egészség-környezet-élelmiszer kapcsolatrendszer terén közölt releváns és friss eredményeket szemlézzük.

\section{SZAKIRODALMI ÁTTEKINTÉS -} LITERATURE REVIEW

\subsection{Környezetvédelem és környezettu- datosság - Environmental Protection and Environment Consciousness}

A fenntartható fejlődés fogalmának elterjedése előtt már megszületett az a gondolat, hogy a gazdasági növekedés és a fogyasztás olyan formája lenne hosszútávon fenntartható, amely a természeti erőforrásokat és azok megújulását nem veszélyezteti, ezáltal az emberi életet is támogatja, mely a természeti környezet nélkül nem tud életben maradni.

A környezet állapotával és annak az emberi életre gyakorolt hatásával kapcsolatos aggodalmak a 20. század közepén fogalmazódtak meg, de a fokozott környezetterhelés kialakulását a szakirodalomban az ipari forradalom kezdetére datálják (MAJLÁTH, 2009; NAGY, 2011).

A környezetpolitikai célok között legfontosabbak a megelőzés, a környezeti állapot javí- 
tása és bizonyos esetben a várható negatív hatások minimalizálásának lehetősége (DOMBI, 2012:41). Itthon törvényi szinten megjelenik a környezetvédelem fontossága ${ }^{1}$ (FARSANG, 2011).

A nemzetközi kutatások és jelentések alapján a legnagyobb problémát a technokrata civilizáció fenntarthatatlan trendjei jelentik az energia- és a természeti források szempontjából. Ezek a Föld eltartóképességének határait veszélyeztetik. A tanulmányok a negatívan ható bioszféra változásokat, a biodiverzitás és az ökoszisztéma komoly sérülését (LÁNG, 1980; WACKERNAGEL és REES, 1996; BAZAN, 1997; HINTERBERGER et al., 2003; RÖPKE, 2004; KEREKES, 2011; CSETE, 2012; SZLÁVIK, 2014), a talaj mint feltételesen megújuló multifunkcionális erőforrás minőségi romlását (LÁNG et al., 1983; VÁRALLYAY, 2002; NÉMETH és VÁRALLYAY, 2015), illetve a levegőszennyezést (KEREKES, 2011) említik. Ezen problémákra lehet megoldás az oktatás, a tudat és az értékrendszer formálása, továbbá az infrastruktúra, a technológia és a termékek átalakulása. Ehhez minden szereplő, aktor, illetve stakeholder bevonása szükséges (KEREKES, 2011).

A fenntartható fejlődés útjára lépés során az egyik alapvetés a rossz fogyasztási minták átalakítása, melynek egyik kulcsfontosságú formája a környezettudatos egyéni magatartás kialakítása. A környezettudatosság definiálásához öt komponenst kell összekapcsolnunk: ökológiai tudás, környezeti értékek, illetve attitűdök, cselekvési hajlandóság, továbbá tényleges cselekvés (NEMCSICSNÉ, 2005; MARJAINÉ et al. 2012).

A környezettudatos attitűd és magatartás nem új trend napjainkban. A tudatos életvitel kapcsán az egyik első és legismertebb magatartásforma és gondolkodásmód. Beletartozik az aktív környezetbarát és környezetvédő politizálás és a kapcsolódó szerveződések (HOFMEISTER-TÓTH et al., 2011). Számos ma már világszinten ismerté vált irányzat alakult ki ez alapján. (Példa: Greenpeace - több mint 2,8 millió követővel világszerte.)

Egy másik értelmezésben BANERJEE és
MCKEAGE (1994) a környezettudatosságot, mint különböző hiedelmek együttesét határozták meg, melyek az ember és természet kölcsönhatására hívják fel a figyelmet, illetve a környezet emberfelettiségére (SCHÄFFERNÉ DUDÁS, 2008). Környezettudatos cselekvési típusokat MEFFERT és KIRCHGEORG (1994) pedig a következők szerint különítették el (NAGY, 2011):

1. A hagyományos feldolgozású termékek fogyasztásának csökkentése, illetve róluk való lemondás.

2. Keresletmódosítás - környezetbarát termékek vásárlása a hagyományos helyett.

3. Környezetbarát termékek fogyasztása.

4. Részvétel az újrahasznosításban, szelektív hulladékgyüjtésben.

5. Környezettudatos panasz, tiltakozás.

A globális problémaként felmerülő klímaváltozás és a különböző környezetvédelmi témák olyannyira nagy fogyasztói rétegeket kezdtek el foglalkoztatni, hogy vállalati szinten is egyre nagyobb szervezetek csatlakoztak a különböző környezetvédelmi mozgalmakhoz, mint a Coca-Cola, a General Electric, a Toyota, az IBM és még sokan mások (BUSH, 2008). Ezen cégek hamar észlelték a fogyasztók részéről megnövekedett ökológiai tudatosságot, a minimalista, takarékosabb, tiszta, zöld termékek előnyben részesítését, és CSR tevékenységükkel, illetve termelésük, kommunikációjuk fejlesztésével keresik a fogyasztók kegyeit (ZSOLNAI, 2001). HAYTKO és MATULICH (2008) azt is megállapították kutatásaik során, hogy a rutinszerü környezettudatos fogyasztók a „zöld” termékeket és szolgáltatásokat részesítik előnyben, és az árérzékenységük csökken ezen termékek esetében.

Hazai viszonyokat tekintve a környezettudatos életforma vagy környezetvédelem már nem csak morális kérdés. Komoly piaci vonzerővel rendelkezik. A Tudatos Vásárlók Egyesülete, a Magnet Bank és a GfK együttmüködésével létrehozott Tudatos Vásárlói Piaci Jelentésben arról számolnak be, hogy a hazai háztartások közül is egyre nagyobb arányban választják a környezettudatos, az etikus és/

${ }^{1}$ Az 1995. évi LIII. Környezetvédelmi törvény (1995. évi LIII. Törvény a környezet védelmének általános szabályairól) célja a környezet elemeinek és folyamatainak védelme, a fenntartható fejlődés környezeti feltételeinek biztosítása. A rendelkezés a környezeti elem fogalmába sorolja: föld, víz, levegő, élővilág, ember által létrehozott épített környezet (FARSANG, 2011:1). 
vagy a biotermékeket. 2014 és 2016 között 359 milliárd Ft feletti összeget költöttek olyan élelmiszerekre, melyek a környezet, a közösség vagy a saját egészségüket támogatták. Ezek közül is kiemelkedik a piacok és a biopiacok forgalma, mely 334 milliárd Ft volt. Ezen kiadások az összes élelmiszercélú háztartási kiadás közel 15\%-a volt 2016-ban, bár a bio- és egészségvédő termékek árszínvonala feltételezhetően magasabb. Az élelmiszereken túl nőtt a közösségi közlekedés, a biciklizés és a környezetbarát technológiák támogatottsága is (TVE, 2017).

\subsection{Az egészség értelmezési keretei - Interpretations of Health}

A magyar nyelv kedvez az egészség fogalmának megértésében, hiszen az „egész-ség”-et, a teljességet jelenti (BARABÁS, 2006). A klaszszikus megközelítésekben viszont jellemzően a negatív tényezőktől való mentességgel szokták megfogalmazni, mint hogy az az egészséges, aki nem beteg, nincs testi fájdalma, sem érzelmi hiányérzete, vagy más lelki zavara (TOMCSÁNYI 2011). Ez alapján az egészség dimenzióit is szétválaszthatjuk, mint a biológiai egészség, a lelki egészség, a mentális egészség, az emocionális egészség és a szociális egészség (DÖRNYEI et al., 2014), mégis összetett fogalmi hálóban érdemes értelmezni (BARABÁS, 2006).

GROSSMANN (1972) az egészség előállításának költségeit modellezte. Szerinte az egyén egészsége a kor előrehaladtával nem feltétlenül kell, hogy amortizálódjon vagy elvesszen, hanem a megfelelő „eszközök” segítségével fenntartható vagy javítható. Az egyén - e modell szerint - aktív szerepet vállal, mind saját egészségtőkéjének előállításában, mind a rendelkezésére álló (a születéssel hozott) egészségtőke fogyasztásában is. Az előbbibe a „beruházok” (pl. az iskolázottság növelése), az utóbbiba a „pazarlások” (pl. a kockázati magatartások) tartoznak. A beruházások megtérülnek, mégpedig nem csak a jobb egészségi állapotban, hanem más javakhoz való hozzájutásban (pl. munka, jövedelem), és azok használatának élvezhetőségében (pl. szabadidő eltöltésében) (FÜZESI és VARGA, 2014). Az étkezésre fordított fokozott figyelem például ennek a tőkének a megóvásában segíthet. Azonban az egészség vagy annak megőrzése nem csak az egyén fe- lelőssége, hanem társadalmi érdek is, hiszen az a tapasztalat és tudás, amit az ember élete során „felhalmoz”, kincs és érték a társadalom számára (HUSZKA és SÜLE, 2014), melyet kamatoztatni a legtöbb esetben csak egészségesen képes.

Az általános egészségnek kedvez a mai fogyasztói társadalom hozzáállása, hiszen az egészséges életmóddal kapcsolatos termékek és szolgáltatások kereslete növekedett az elmúlt évek során (GAÁL et al., 2011; GFK, 2012; FÜZESI és VARGA, 2014).

A KSH (2018) eredményei alapján a 16 éven felüli lakosság 59,5\%-a elégedett az egészségével, míg a 16-25 év közötti fiatalok 91\% ítéli nagyon jónak azt (KSH, 2015), ám ez a kor előrehaladtával egyre alacsonyabb arányt mutat. A felnőtt lakosság körében 2010 óta kismértékü, de pozitív tendencia látszik, akkor 55\% volt ez az arány. 2009-hez képest mindkét nem képviselői elégedettebbek, de EU-s összehasonlításban ezzel az eredménnyel a sereghajtók közé tartozunk az EU átlag (67,4\%) alatti eredményünkkel (KSH, 2018). A magyar lakosság 55\%-a számolt be krónikus betegségről (magas vérnyomás, szív-ér rendszeri, illetve mozgásszervi betegségek - főleg hát- és gerincfájás, továbbá ízületi kopás, anyagcsere betegség, mentális betegségek). Kiderült az is a felmérésből, hogy a lakosság több mint fele jár szűrővizsgálatokra. A lakosság közel egyharmada dohányzik, $5 \%$ bevallottan nagyivó, illetve kétharmada (67\%) nem sportol még napi 10 percet sem. A túlsúlyosak-elhízottak közé tartozik a felnőtt lakosság több mint fele (2014 és 2017: 54\%), a középkorú férfiaknak pedig a 71\%-a $(\mathrm{KSH}$, 2015b, KSH, 2018).

A KSH (2014b) eredményei alapján hazai viszonylatban összességében elmondható, hogy az egészséges életmód egy népszerü közéleti témakör, ám a magyar állampolgárok esetében mégsem érjük el azt a kívánt szintet, mely esetében csökkenhetne a helytelen táplálkozásból, mozgáshiányból vagy egyéb rizikómagatartási tényezőkből fakadó korai megbetegedések, halálesetek aránya (FÜGE et al., 2015). A 2016. évi eredmények csak mérsékelt javulást mutatnak a 2014. évi eredményekhez képest (KSH, 2017b).

Itt érdemes megemlíteni, hogy sok esetben az egészségmodelleket, egészségmagatartási 
modelleket alkalmaznak együtt vagy külön-külön az egészségre ható tényezők súlyának megismerésére. Az egészségmagatartás értelmezésénél több szakirodalom úgy összegezi, hogy körébe tartozik minden viselkedéselem, attitűd, amelyet a személy azért képvisel, hogy megvédje, elősegítse vagy fenntartsa egészségét (HARMATH, 1978; HARRIS és GUTEN, 1979; BAUM et al., 1997; SZAKÁLY, 2008; DÖRNYEI et al., 2014; BRÁVÁCZ, 2015), akár tudatosan teszi mindezt, akár rutinból (HARMATH, 1978). Ez a MATARAZZO (1984) által preventív egészségmagatartásnak nevezett típus. Létezik emellett a kockázati vagy egészségrizikó viselkedés, amely a fent említett tényezők figyelmen kívül hagyását jelenti, legjellemzőbben dohányzást, egészségtelen táplálkozást, alkoholfogyasztást értünk ez alatt (MATARAZZO, 1984). Az Egészségtudományi Fogalomtárban az egészségtudatos magatartás értelmezése is hasonló, sőt igencsak megegyezik ezzel, azaz az egyén szemléletének, viselkedésének, tevékenységének összessége annak érdekében, hogy minél tovább és minél egészségesebb maradhasson (EGÉSZSÉGTUDOMÁNYI FOGALOMTÁR, ni).

\section{3. Élelmiszerfogyasztás és trendjei - Food Consumption and Food Trends}

Az élelmiszerek megítéléséről és minőségéről három tényező alapján szokás beszélni. Az első az élettani érték (tápanyag-összetétel, például fehérjék, zsírok, és a nem tápanyag összetevők - rostok, probiotikumok); a második az élvezeti érték (íz, illat, aroma, szín, állag); a harmadik pedig az alkalmassági érték (fogyasztásra vonatkozóan - elkészítés, csomagolás, csomagoláson feltüntetett információk) (OECD in ÁDÁNY, 2011:412)

Az élelmiszerfogyasztás összetett jelenségként való vizsgálatát LEHOTA (2001) alapján BRÁVÁCZ (2015) az alábbiakkal magyarázza:

- az egyénhez kapcsolódó biológiai tényezők (érzékszervi tényezők, betegségek, egyéni érzékenység stb.),

- az élelmiszerfogyasztás szerkezetét (mennyiségét, összetételét) meghatározó ár és jövedelmi arányok, azaz közgazdasági tényezők (jövedelem megváltozott reálértéke, más termékekkel való helyettesíthetőség) (HORVÁTH, 1997),
- az élelmiszer elfogadását, elutasítását vagy az élelmiszerekkel kapcsolatos imázs kialakulását meghatározó pszichológiai tényezők,

- a társadalmi beágyazottságot meghatározó szocio-demográfiai tényezők (elsődleges, másodlagos és referencia csoportok szerepe, státus, családon belüli szerep),

- az egyéni, társadalmi és pszichológiai tényezőket integráló tanult értékek és szokások összessége, azaz kulturális tényezők (LEHOTA, 2001 idézi BRÁVÁCZ, 2015:310).

\subsubsection{Táplálkozás és étkezés - Nutrition and Eating}

Az élelmiszerfogyasztás előtt érdemes megvizsgálni magának a táplálkozásnak és az étkezésnek a fogalmát. Az egészségünkre megannyi tényező hathat, ám van, amit életmódunkkal befolyásolhatunk, ilyen a táplálkozásunk. Ma már általánosan elfogadott álláspont, hogy a legtöbb esetben az egészséges táplálkozás hatékonyabb módja az egészség megőrzésének, mint a gyógyszerek fogyasztása (HASLER, 2002; WILLIAMS, 2005 idézi SZAKÁLY, 2011). A táplálkozás kapcsán ki kell emelni, hogy ez egy összetett folyamat, nem csak az étkezés szinonimája. A táplálkozás során az élő szervezet önmaga fenntartásához szükséges tápanyagokat felveszi, az anyagcsere folyamatokhoz szükséges anyagokat a szervezetbe juttatja (RIGÓ, 2002). Az étkezés a táplálkozás hat szakaszából (KOZMÁNÉ, 2015) az első. Az étkezés fogalma alá az étel- és italfogyasztás, továbbá a körülmények, melyek ezalatt körülvesznek minket, tartoznak (HENTER et al., 2013). Azonban ebben a szakaszban dől el, hogy milyen tápanyagok jutnak el a szervezetbe (KÖNYVES és VARGÁNÉ CSOBÁN, 2015). A szervezet a táplálékkal energiát vesz fel, melyeket különböző célra használ, mint anyagcserére (légzésre, szívverésre, testhő fenntartásra), specifikus - dinamikus hatásra (táplálék feldolgozásra), izommúködésre, fizikai aktivitásra (harántcsíkolt izomzat múködésére), illetve növekedésre. Ezért is fontos táplálkozásunknál az energia bevitel, amelynek hőmennyiség mértékegysége a jól ismert kalória (cal) (HENTER et al., 2013). 
Az étkezés javasolt gyakoriságát befolyásolhatja betegség vagy amiatti speciális diéta, de a legmegfelelőbbnek a szakemberek a napi öt alkalommal történő étkezést javasolják, melyek a reggeli, a tízórai, az ebéd, az uzsonna és a vacsora (BACHMANN et al., 2011; HENTER et al., 2013). Egy az Egyesült Államokban végzett kutatás megállapította, hogy a napi étkezések száma alapjában meghatározza a testtömegünket és ezáltal egészségünket is. Míg a túlsúlyos egyénekre a napi általában kétszeri, de ugyanakkor magas kalória bevitel jellemző, addig a normál súlyú kategóriába tartozók esetében több mint háromszori étkezés volt a jellemző (BACHMANN et al., 2011). A hazai dietetikusok ajánlása is ez, a bevitt táplálék mennyiség, minőség, összetétel és tápanyagtartalom figyelembevétele mellett (ÁGFALVI, 1987; KISS és SZAKÁLY, 2015). A hazai társadalomban egyre inkább jellemző a napi többszöri étkezés. Az elmúlt években 22\%-ról 40\%-ra nőtt a naponta négyszer vagy többször étkezők aránya, bár a meleg étkezések száma ennek ellenére visszaesett, így vélhetően a nassolások száma nőtt (GFK, 2016a). Ezenkívül a dietetikusok a változatos étrendet javasolják, melyben arányosan kell lennie a legfontosabb tápanyagoknak. A külföldi minták alapján el is készítették az OKOS Tányért, mely bemutatja az ajánlott arányokat a különböző élelmiszerek esetében (MDOSZ, 2016).

\subsection{2. Élelmiszerfogyasztás globálisan és hazánkban - International and National Food Consumption}

A világ lakosságának az élelmiszerpazarlást és -veszteségeket is tartalmazó, élelmiszer-mérlegek alapján számított élelmiszerfogyasztása 1995-ben 2.663 kcal volt naponta, egy fóre vetítve; ami 2013-ra 2.884 kcal-ra nőtt (FAOSTAT, 1. ábra), ez 9\%-os növekedést jelentett. Ennél sokkal nagyobb arányban, 20\%-kal emelkedett az állati termékek fogyasztása, fejenként napi 428 kcal-ról 514 kcal-ra ugyanezen időszak alatt. Ahogyan az 1. ábrán is nyomon követhető, az élelmiszerfogyasztás napi 2800-3700 kcal között van, és ennek növekedése általános trendnek tekinthető - ez gazdasági értelemben tekinthető fogyasztásnak, tehát nem egyezik meg az élelmiszer-bevitellel. Mivel az ember fiziológiai szükségletei feltehetően nem indokolják ezt a növekvő tendenciát, a többlet vélhetően a pazarlás és a túlfogyasztás növekvő mértékéből adódik. A fejlettebb régiókban az állati eredetű termékek fogyasztása kb. duplája, háromszorosa a kevésbé fejletteknek.

A hazai élelmiszerfogyasztási kutatásokból is az derül ki, hogy a mai fogyasztók már jóval többet várnak el az élelmiszerektől, mint a jó élvezeti érték (SZAKÁLY, 2011). Tudományos szempontból felértékelődött az élettani hatásuk, és a fogyasztói elvárások is emelkedtek. Láthatjuk például, hogy az elmúlt évek folyamán hogyan nőtt a különböző egészségvédő élelmiszerek iparága (SZAKÁLY, 2011).

Magyarországon a Nemzeti Agrárgazdasági Kamara statisztikái alapján az élelmiszeripar a harmadik legnagyobb ipari ágazat 2600 milliárd forint feletti termelési értékkel (folyó áron), és a második legnagyobb az ágazatban alkalmazottak száma alapján (91 987 fó). Az élelmiszeripar termelése és értékesítése folyamatosan növekedett az elmúlt években (KSH, 2017a). A háztartások egy főre jutó összes kiadásából az élelmiszerre költött arány 23\%, szemben az uniós 13\%-os átlaggal. (ÉFOSZ, 2016a, MTI, 2017). A KSH (2015a) beszámolójából azonban az is kiderült, hogy 2013-ban az egy főre jutó éves élelmiszerfogyasztás 615 kilogramm volt, - ami napi 2 kilogrammot jelent -, és ez 4,3\%-kal kevesebb, mint a megelőző öt év átlaga. Abból, hogy a fogyasztás mennyisége csökkent, miközben az élelmiszeripar termelése és értékesítése növekedett, részben következtethetünk arra is, hogy a fogyasztók többet költenek a megvásárolt élelmiszerre, ám annak mennyiségét csökkentették. Ez egybecseng azokkal a nemzetközi és a hazai tanulmányokkal, amelyek szerint egyre erősebb a tudatos vásárlás és a minőségi termékek preferálása, ami kedvező az egészségtudatosság és a fenntarthatóság szempontjából (SZAKÁLY et al., 2015; GFK, 2016a, b). Ez derül ki egy 2014-ben készült kutatásból is, amely már az új igények és keresleti tényezők tükrében határozott meg tíz egészség-centrikus irányzatot a funkcionális élelmiszerfogyasztásban, melyek között egyaránt jelen vannak a természetes összetevőkből előállított gyermek ételek és a táplálék-kiegészítők is. Ezek a termékek több milliárd dollár értékü bevételt jelentettek az elmúlt évek- 
ben gyártóik, forgalmazóik számára (SLOAN, 2014). A SLOAN (2014) által vizsgált mintázatokból is látszik, hogy az élelmiszereken való információközlés egyre komolyabb keresletindukálóként hathat bizonyos termékek piacán.

1. ÁBRA
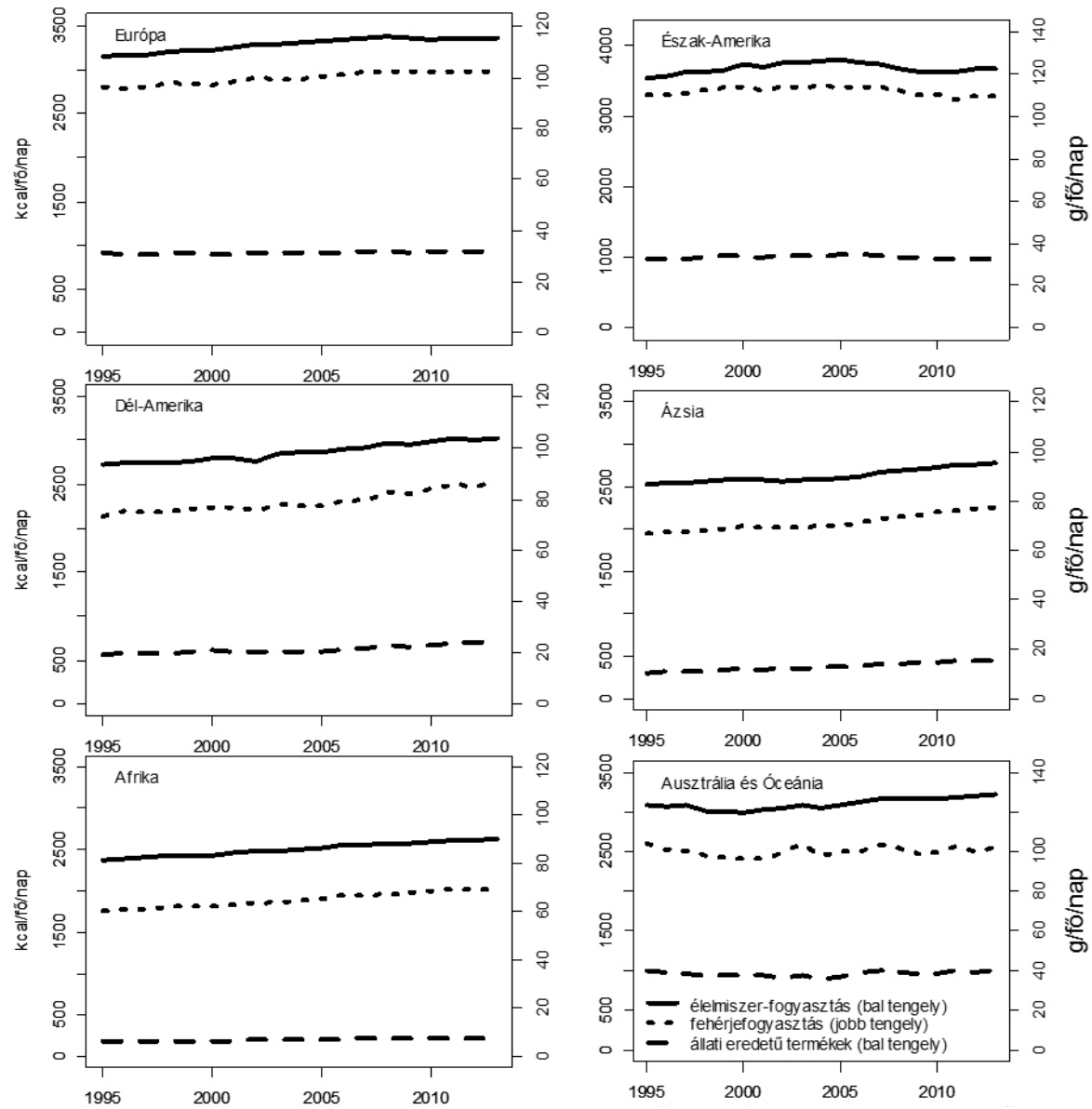

FIG. 1

Az egyes élelmiszerfogyasztási jellemzők regionális eloszlása (Regional Distribution of Food Consumption Characteristics)

Forrás (Source): FAOSTAT, 2018

Megjegyzés (Notes): From the top left figure: Europe, North-America, South-America, Asia, Africa, Australia and Pacific. Solid line: food consumption (left axis); dotted line: protein intake (right axis); dashed line: animal products (left axis). Left axis: $\mathrm{kcal} / \mathrm{cap} /$ day. Right axis: $\mathrm{g} / \mathrm{cap} /$ day.

Az összes élelmiszerfogyasztáson belül egyharmados arányban az állati eredetü termékeket (hús, hal, tej, tojás) választják a fogyasztók, ám kismértékben csökkent ezek népszerüsége az évek során (4\%) (KSH 2015a), ami a fenntartható fogyasztás szempontjából pozitív tendencia (VETÓNÉ MÓZNER, 2012). A növényi termékek aránya (liszt, rizs, zöldségek, gyümölcsök és egyéb növényi eredetû élelmiszerek) 3\%-kal nőtt az elmúlt években, kivétel ez alól a burgonya, mely valószínúleg az árváltozás miatt vesztett népszerüségéből. A gyümölcsfogyasztás esetében találták a legpozitívabb változást, ami egy főre vetítve 5 kilogrammal nőtt 
a 2008-2012 átlagához képest. Ezen belül is a hazai gyümölcsök eladása volt kimagasló, ami 10 kilogramm/fö-vel több volt, mint 2012-ben. Mérséklődött továbbá a zsiradék-felhasználás, továbbá csökkent az alkoholfogyasztás 6,2\%kal, ami leginkább a sörfogyasztást érintette (KSH, 2015a). Ezek a tendenciák egybecsengenek az egyre több tanulmányban megjelenő egészségtudatosabb élelmiszerfogyasztás trendjével. Az élelmiszerek összetevőivel kapcsolatban a fogyasztók a legveszélyesebbnek az adalékanyagokat, a koleszterint, a magas hozzáadott só- és cukortartalmat, az állományjavítókat, a színezékeket és a sertészsírt tartják (SZAKÁLY, 2008).

\subsubsection{Az étkezés mint az életstílus szimbólu- ma - Eating as the Symbol of Lifestyle}

Ahogy az előző fejezetben is említésre került, az étkezés egyre erősebb transzparenciával bír életünkben. Az étkezés, annak elö- és elkészítése, elfogyasztása mindig fontos része volt az emberek mindennapi életének, de ilyen fokozott érdeklődést a témával kapcsolatban korábban nem tapasztalhattunk (TÖRÖCSIK, 2014). Egyre inkább a figyelem középpontjába helyeződött az ételek elkészítése, azok esztétikai értéke, az ízvilág egzotikuma vagy épp a hagyományossága. A piaci szereplők is felfedezték, hogy ma már egy gasztroblog vagy receptoldal üzemeltetése, vagy épp egy tv müsor elkészítése, fesztivál megszervezése piacképes, sőt ezreket vagy milliókat vonzhat. Az étkezési szokások vizsgálatára számos kutatás irányul, például az orvostudományi, a pszichológiai, a szociológiai vagy egyéb diszciplínák mentén. Jelen tanulmányban elsősorban a fogyasztói magatartás szempontjából kerül kifejtésre.

Az ételfogyasztásnak az elmúlt években fokozatosan ki- és átalakultak a megatrendjei (2. ábra), amelyek esetében az étkezés már nem csak az éhségcsökkentésére - életfunkciók fenntartására - irányul (TÖRÖCSIK, 2010). Az étkezés mint élvezetforrás a korábbi tendenciákhoz képest is tovább erősödött (TÖRŐCSIK, 2014). Többszintű funkcionalitása került a középpontba. Bár a társadalmi státusz és az anyagi helyzet erősen befolyásolhatja ezen sokszínúséget (DARMON és DREWNOWSKI, 2008).

TÖRŐCSIK (2010) az ételfogyasztás esetében az életstílust kifejezó életstílus transzparenciát látja, mely a food-trendek követésével reprezentálódik. Sok esetben a fogyasztó nem csak az étel elfogyasztására vágyik, hanem szakértője szeretne lenni egyes ételeknek, italoknak, mely az evésen túl plusz élményt nyújt számára (ELIAS, 1987 idézi TÖRŐCSIK, 2010). További élmény-orientált étkezési trendek még a mood food, a sensual food, a wellness food, a show food, a retro food, a strange food vagy a fúziós konyha (TÖRŐCSIK, 2010). Ezek mind többletélményt adnak egy átlagos étkezésen túl.

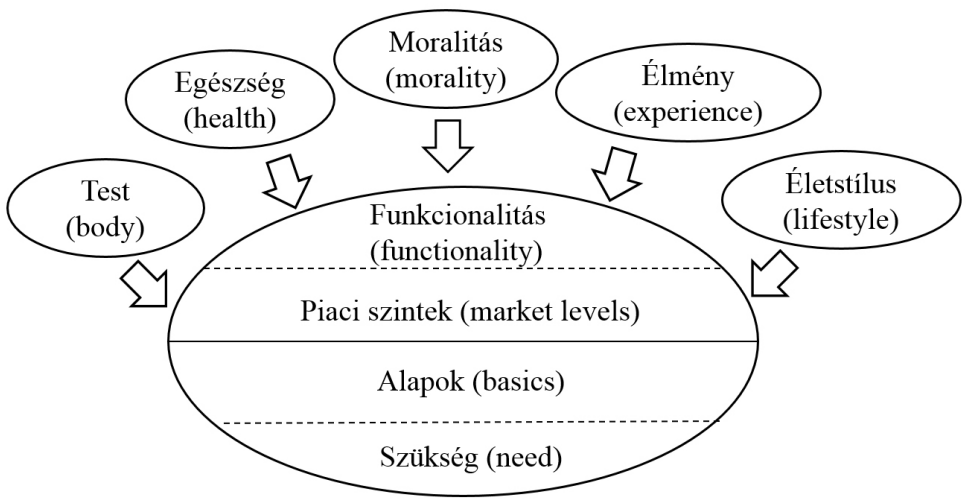

2. ÁBRA

$$
\begin{gathered}
\text { Az élelmiszerválasztást befolyásoló trendösszefüggések } \\
\text { (Trends Influencing Food Choice) }
\end{gathered}
$$

FIG. 2

Forrás (Source): TÖRŐCSIK, 2014 


\subsection{Az egészség - élelmiszer - környe- zet kapcsolatrendszer - Nexus of Health, Food and Environment}

$\mathrm{Az}$ egészség és az élelmiszerek interakciója kapcsán a nem-fertőző betegségek (noncommunicable diseases, NCD), a civilizációs betegségek egyes csoportjai kerülnek előtérbe, melyeket életvitelünk és környezetünk egyaránt előidézhet. A legjellemzőbb betegségek a kardiovaszkuláris betegségek, a daganatos betegségek, a légzôszervi betegségek, a metabolikus betegségek és a diabétesz. Ezen betegségek kialakulásában a nem-megfelelő táplálkozás mint rizikótényező komoly szerepet kaphat. Ennek bizonyítását hazai és nemzetközi tanulmányokban is tetten érhetjük (SZAKÁLY et al., 2015; TARRY-ADKINS és OZANNE, 2017). Az NCD betegségek 38 millió ember haláláért felelősek minden évben (WHO, 2015). Hazai szinten magas a keringési, az emésztőrendszeri és a daganatos betegségek aránya világviszonylatban (TOMPA, 2011; URBÁN, 2014; KRISTON és PIKÓ, 2016), ezek kialakulásának vizsgálata és megelőzése népegészségügyi prioritássá vált (KRISTON és PIKÓ, 2016).

A Gfk 2016. évi felmérése alapján „az általános étkezési gyakorlatba átment a többször keveset elv, egyre többen fordulnak az egészséges élelmiszerek, így a zöldség és gyümölcs, a teljes értékủ gabonák, a halak felé, valamint bekerült a köztudatba az elégséges folyadékbevitel szükségessége" (GFK, 2016b).

Amennyiben az egészségünkre ható tényezóket vizsgáljuk - a korábban már említett számos egészségmodell adhat választ. Melyek ezek a tényezők, és közvetett vagy közvetlen módon hatnak egészségünkre? Az elmúlt évtizedben megerősödő humán centrikus egészségmodellekkel szakító elméletek indokoltságának bemutatása jelen bekezdés célja. Míg a közvélekedésben és a tudományos életben is az ember saját magára gyakorolt hatásának vizsgálata van a fókuszban, addig számos kutatás már arra hívja fel a figyelmet, hogy a társadalmi, a gazdasági, az egészségügyi, a természeti és az épített környezet determinálja egészségi állapotunkat. Ezen tényezők összhatását foglalja össze DARÓCZI (2004) is az egészségi állapot termelési függvényében. A modernizáció hatására kialakult ember és környezete közötti egyensúlyzavar enyhítése vagy akár helyreállítása, harmónia megteremtése egyre több tudományterületet (PIKÓ és BAK, 2005; SZABÓ, 2016) és közéleti szerveződést mozgat meg. Továbbá létrehozta az ökológiai egészség fogalmát, illetve a környezet-egészségtan tudományágát a megelőző orvostan területén (PIKÓ, 1998; ÁDÁNY, 2011; BENTLEY, 2013). Egészséges környezet nélkül nem beszélhetünk fenntartható egészségről. MCGINNIS és munkatársai (2002) szerint a szociális és természeti környezet hatása az egészségre $45 \%$-ot tesz ki, míg egy másik felmérésben a természeti környezet és a genetika befolyása megegyezik, 10-10\% (KUZNETSOVA, 2012). A természeti környezet állapota komoly hatással van a humán egészségre - különösen a gyermekekre (NEIRA et al., 2008; VITRAI és VOKÓ, 2006), hiszen többek között a levegö-, a föld- vagy a vízszennyezés közvetve vagy közvetlenül súlyos élettani károkat okozhat, mely a fiatal szervezetben akár visszafordíthatatlan folyamatokat indíthat be.

Kiegyensúlyozott társadalmi környezet és jólét nélkül sem valósulhat meg a fenntartható egészség (MCGINNIS, 2002; KERK és MANUEL, 2008; KISS, 2015). Ezt megerősíti a WHO 1946-os definíciója is, mely nem a betegség hiányában látja az egészséget, hanem a teljes testi, lelki és szociális jóllét állapotában (MORGAN, 2009). Így azt mondhatjuk, az egészség egyaránt rendelkezik objektív és szubjektív dimenzióval. A társadalmi hatások (iskolai végzettség, foglalkozás, jövedelemszint, lakókörnyezet, lakáskörülmények, a szociális helyzet és az életkörülmények illetve tágabb környezetben a jólét, a jóllét, a szegénység, az urbanizáció, a jövedelmek eloszlása, a társadalmi státusz, a munkanélküliség vagy a vallás) tehát erősen determinálják az egészségünket és az egészségügyhöz való kapcsolatunk minőségét is (KOPP et al., 1999; UZZOLI, 2000; WILKINSON és PICKETT, 2009; LACZKÓ, 2010; KOCSIS, 2010). A legtöbbször bizonyított globális szintü összefüggés a társadalmi hatások kapcsán, hogy jellemzőbben alakul ki a rizikómagatartás, illetve emiatt egészségügyi panaszok és konkrét betegségek, akkor, ha az alacsonyabb státuszú egyénekről van szó (KOPP et al., 1999; UZZOLI, 2000; WILKINSON és PICKETT, 2009). 
Az egyik nemzetközi mozgalom, mely a fenti gondolatmenetre épül a(z) ONE Health, ami azt szorgalmazza, hogy ha az ember nem bánik megfelelően környezetével, az a saját egészségére üt vissza különböző betegségek formájában (RABINOWITZ et al., 2013; CDC, 2017). Ez a mozgalom leginkább az állategészségügy kiemelt prioritásként való kezelése kapcsán különbözik a többi mozgalomtól, így tudományos vizsgálatai is jellemzően az állategészségtan és azzal kapcsolatos környezet-egészségtan témakörben jelentek meg az elmúlt években (CDC, 2017).

$\mathrm{Az}$ egészségnek különböző modelljeit vázolták fel a szakemberek az évek során. Az 1974-ben publikált jelentés, a kanadai Lalonde Report (1974) tartalmazta először a ma már jól ismert ábrát, az ún. egészségmezőt és a hozzá kapcsolódó elméletet. Ezen elmélet szerint az egészség szempontjából a legnagyobb jelentőséggel négy terület bír, nevezetesen: a biológia, életmódbeli és környezeti tényezők, valamint az egészségügyi ellátórendszer. Kulcsfogalma az életmód lett, melynek formálásában már az orvosok, egészségfejlesztők mellett például a pszichológusok, pedagógusok, szociális munkások is jelentős szerepet kaptak (KISS-TAMÁS, 2005; FÜZESI és VARGA, 2014). Ez egybecseng a korábban bemutatott kutatók eredményeivel.

A másik, részletesebb modell a négy szintû egészségmodell, melyben VITRAI és VOKÓ (2006) az egészséget befolyásoló tényezőket sorolják be. Ebben a makro (külső ív) szinten találhatóak: kulturális, társas-, fizikai, gazdasági, politikai és egészségügyi ellátási környezet. A mikro (közvetlen) szinten vannak: értékek, család, lakó- vagy munkahely, anyagi helyzet, „hétköznapi szabadság”, háziorvos. Míg az egyéni szinten: magatartás, képzettség, lelki tulajdonságok, biológiai tulajdonságok, illetve ehhez kapcsolódva a cselekvés szintjén: társas tevékenység, azon belül egyéni és szervezeti tevékenységek (VITRAI és VOKÓ, 2006).

A harmadik - most bemutatásra kerülő - egészségmodellben is a szocio-ökológiai, kulturális és természeti környezettől indulva BENTLEY (2013) már összesen 13 tényező befolyásoló hatására hívja fel a figyelmet. Az egészségre ható tényezóket 5 szintbe sorolja be: 1. általános szocio-ökonómiai, kulturális és természeti; 2. élet- és munkakörülmények, 3. társadalmi és közösségi hálózatok, 4. egyéni életstílus faktorok; 5. Demográfiai és egészségügyi faktorok. A többihez képest a közösségi hálózatok külön kiemelését és a sorrendiség változtatását láthatjuk ebben a modellben.

A leginkább közös a három egészségmodell felfogásban, hogy mindegyik esetében humán-centrikus felfogásról beszélhetünk.

Összefoglalva a nép- vagy civilizációs betegségek nagy kihívást jelentenek a társadalom, az egészségügy, illetve a gazdaság számára, ám még annál is nagyobb feladat olyan, a problémák orvoslására kiépített gyakorlati rendszer(ek) létrehozása, amely(ek) komplexen veszi(k) figyelembe a fenti tényezőket.

Ahogy a 3. ábrán is látható, a fenntarthatóság kérdéseivel foglalkozó szakirodalom az elmúlt szúk két évtizedben jelentősen kibővült. A növekedés az egészség - élelmiszer - környezet kapcsolatrendszer terén is intenzívnek mondható, bár ez a specifikus terület nagyságrendileg kevesebb, évi kb. 6-80o közleménnyel gyarapszik a Web of Science adatai alapján. Ezen szegmens éves növekedési üteme a közlemények száma alapján 2001 és 2017 között hétszer is meghaladta a másik két, általánosabb szakirodalmi kört.

Az épített és természeti környezet összefüggésében egyre nagyobb nemzetközi figyelem övezi a városiasodás és a fenntartható urbanizáció emberi egészségre gyakorolt hatását (BENTLEY, 2013). A légszennyezés a WHO adatai szerint mintegy 7 millió ember haláláért felelős évente, amely leginkább - a nagyvárosokban különösen - a légszennyezők növekvő aránya miatt van. A környezeti szennyeződés, mely az ipari és mezőgazdasági emisszió, a jármúvek, a háztartások fütés és főzés általi kibocsátásából fakad, nagy veszélyforrást jelent (ANTAL és PÉTER, 2016). Ennek egyik legjellemzóbb hatása az epidemiológiai kutatások által vizsgált oxidatív stressz. Az ellensúlyozó antioxidáns védelmet a táplálékokból nyerhetjük, például C-E vitamin, karotinoidok, n-3 többszörösen telítetlen zsírsavak, szelén vagy flavonoidok formájában (ANTAL és PÉTER, 2016). Ebből láthatjuk, hogy ebben az esetben is a táplálkozás minősége segíthet az egészség megőrzésében, melyet az ember által épített környezet okozhat (ANTAL és PÉTER, 2016). 


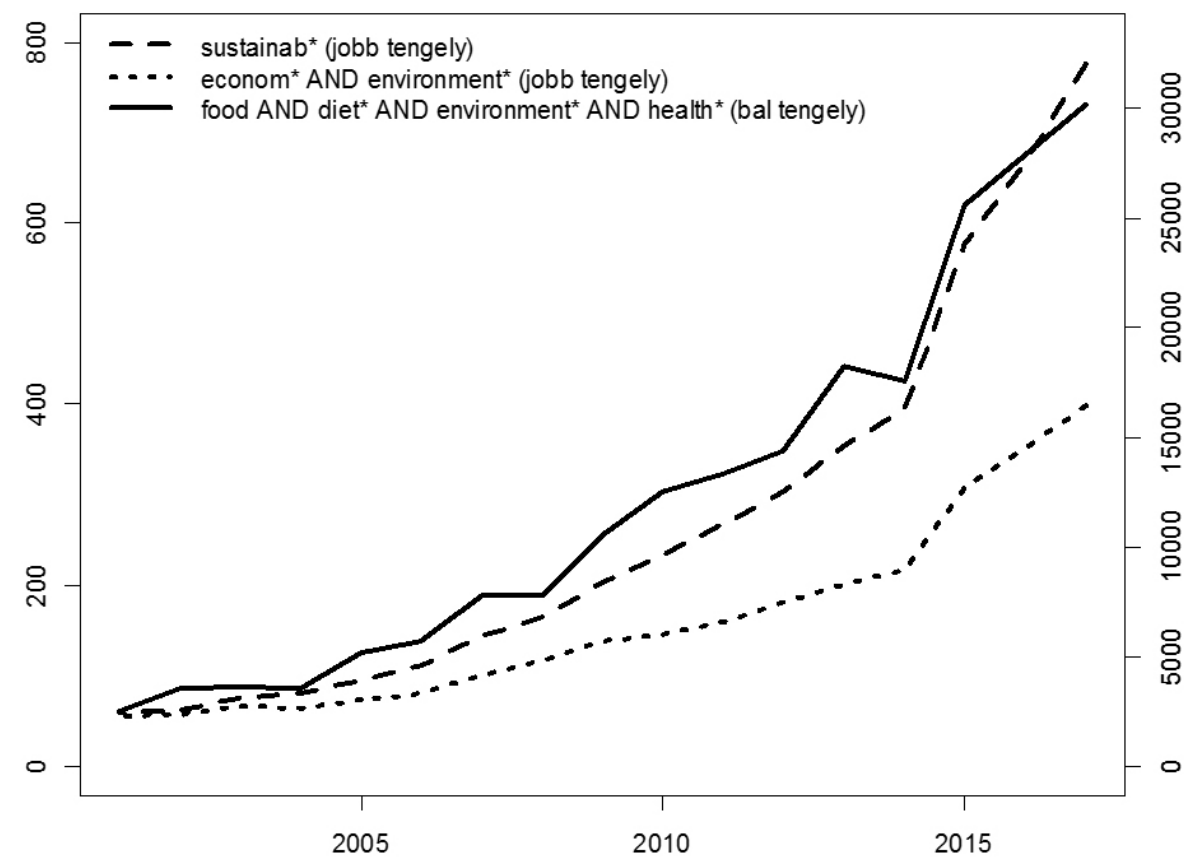

3. ÁBRA

FIG. 3

A Wos keresési eredményeinek száma minden közlemény-kategóriát figyelembe véve (The Number of Wos Search Results Based on Each Bulletin Category)

Forrás (Source): Saját szerkesztés a Web of Science alapján (Own compilation based on Web of Science)

Megjegyzés (Notes): Fenntarthatóság; Gazdaság és környezet; Élelmiszer és étkezés (Sustainabilty and econom+environment-right axis; food + diet - left axis)

VETÓNÉ MÓZNER (2012) és sok más kutató szerint a mezőgazdasági termelésnek van a legnegatívabb környezeti hatása a teljes termék-életciklus során, és kevésbé fontosak a szállítás és csomagolás hatásai. A friss zöldség- és gyümölcsfogyasztásnak kisebb a környezeti terhe (kevesebb energia, földterület, üvegházhatású gáz, kivéve, ha szállítják, mert akkor ugyanolyan mértékben szennyez, mint a húsféléké), illetve az extenzív vagy organikus múvelésből származó termékeknek is kisebb a lábnyoma. Ezt hazai és nemzetközi kutatások egyaránt alátámasztják (SZITA-TÓTH et al., 2000; XU és LANG, 2016; VETTER et al., 2017). A háztartások környezetterhelése kapcsán PRINCES (2005), SCHOR (2005) és WIEDMANN (2006) vizsgálataiban is arra hívják fel a figyelmet, hogy az élelmiszerfogyasztás az ökológiai lábnyom legnagyobb alkotórésze, foglalja össze VETÓNÉ MÓZNER (2012). Kijelenthető tehát, hogy az élelmiszer-előállítás során a mezőgazdasági termelés jellemezhető a legjelentősebb környezeti hatással. A világ édesvízkészletének 70 százalékát az élelmiszer-vertikumban használják fel (TEISL, 2011). Az Európai Unióban a termőterület közel 70\%a az állati takarmányok előállítását szolgálja, ami becslések szerint a mezőgazdaság által okozott biodiverzitás-csökkenés 74\%-áért felel (LEIP et al., 2015). Egy felmérés szerint az élelmiszerek fogyasztásához köthető üvegházhatású gáz (ÜHG) kibocsátás 30\%-át a vörös húsok és 18\%-át a tejtermékek fogyasztása okozza az USA háztartásaiban. Az összes mezőgazdasági ÜHG kibocsátás 81\%-a az állattenyésztéshez köthető, aminek 65\%-át a takarmányok előállítása okozza (LEIP et al., 2015).

BERNERS-LEE és munkatársai (2012) 61 élelmiszer-csoport ÜHG kibocsátását kalkulálták úgy, hogy a kibocsátásokat a technológia fázisához is hozzákapcsolták. Összességében elmondható, hogy a legmagasabb ÜHG 
kibocsátás a különböző húsok előállításánál figyelhető meg (10-15 kg ÜHG/kg). A kibocsátások legnagyobb arányban, kb 80-90\%-ban az alapanyag előállítás szakaszában jelentkeznek, a csomagolás és hútés nagyságrendekkel kevesebb kibocsátást okoz. A szállítás egyedül az egzotikus gyümölcsök csoportjában jelentős, ott viszont meghaladja az összes kibocsátás felét.

LUCAS és munkatársai (2016) nyolc különböző étel adagjára vetített környezeti hatásait mérte fel. A vízfelhasználás adagonként 1832128 liter, a területigény $0,3-9,13$ m2, a szénlábnyom 210-2610 g/adag és az anyagfelhasználás 880-6760 g/adag. Egészségi hatásokat is figyelembe véve, a legkevésbé előnyös étel a vizsgáltak közül a marhahús alapú volt, míg a zöldségekből készült ételek táplálék-lábnyoma rendre alacsonyabb volt a húsételeknél.

Az Európai Unióban az egy főre jutó éves élelmiszer-fogyasztás által indukált anyag-felhasználás 4000-700o kg között van, mivel az elfogyasztott ételek előállításának anyag igénye önmaguk tömegének 8-12-szerese. Az anyagfelhasználás 36-48\%-a húsok, 11-18\%-a tejtermékek es 10-19\%-a gabonatermékek fogyasztásához köthető, ezzel ellentétben a zöldségek és gyümölcsök anyagigénye mindössze 4-6\% (MANCINI et al., 2012). Egy finn felmérés alapján, melyben több mint hatvan étel teljes anyagigényét (total material requirement, TMR) vizsgálták, a legnagyobb anyagigénnyel a birkaragu (mutton casserole) rendelkezik, majdnem $60 \mathrm{~kg} / \mathrm{kg}$ termék. A második helyezett a rangsorban jóval lemaradva $(28 \mathrm{~kg} / \mathrm{kg})$ a dupla burger. Az ételek többsége $3-12 \mathrm{~kg} / \mathrm{kg}$ közötti tartományba esik (KOTAKORPI et al., 2008). Ezek az eredmények kiemelik, mekkora különbség van az egyes ételek előállításához szükséges természeti erőforrások mennyiségében, hiszen egyes esetekben több mint hatvanszoros különbséggel is találkozhatunk.

Az Egyesült Királyság lakossága MACDIARMID és munkatársai (2011) felmérése alapján nagyon távol állnak a javasolt egészséges étrend fogyasztásától. Túl magas a zsírok, a cukor és só fogyasztásuk, de túl alacsony a rostok bevitele. Az élelmiszer-gazdaság szerepe az ÜHG kibocsátásban 30\%, amely azonban sikeresen csökkenthető, összhangban az egészséges étrend követelményeivel. A szerzők viszont felhívják a figyelmet, hogy az optimális étrend kialakítása tudatos egészség menedzsmentet kíván meg: például a lineáris programozással kialakított példa-étrend nók esetében 60\%-kal alacsonyabb húsfogyasztást eredményez, így viszont egyes esszenciális fehérjék pótlása más forrásokból szükségessé válik. BERNERS-LEE és munkatársai (2012) elemzése alapján a brit étrend fenntarthatóvá alakításával az egész brit gépjármü-állomány kibocsátásának felével lehetne csökkenteni az Egyesült Királyság éves ÜHG emisszióját. MASSET és munkatársai (2014) igen széles szakirodalmi áttekintésben hangsúlyozzák, hogy egyes ma is létező regionálisan jellemző étrendek (mediterrán, északi) illetve az állati eredetű termékeket csökkentett mennyiségben tartalmazó étrendek alacsonyabb ÜHG kibocsátással, továbbá egyértelműen pozitív egészségi hatásokkal jellemezhetők (egyes krónikus betegségek és elhízás megelőzése).

WESTHOEK és munkatársai (2014) az Európai Unió tagállamaiban, mint magas jövedelmü régióban vizsgálták az étrend alacsonyabb állati eredetű termék-arányának feltételezhető hatását a környezetre és az egészségi állapotra. A tanulmányban bemutatott szcenáriók az állati eredetű élelmiszerek 50\%-os csökkentését modellezik a fogyasztásban, aminek eredményeképpen átlagosan 10\%-al csökkenthető a fehérjebevitel, de ez az EU átlagát tekintve még így is másfélszerese az ajánlott szintnek. Közel 40\%-kal csökkenne viszont a telített zsírsavak bevitele, az ajánlott bevitel szintjét elérve ezáltal. Az ÜHG kibocsátás - szcenáriótól függően - 19-42\%-kal csökkenhetne a referencia forgatókönyvhöz képest (WESTHOEK et al., 2014). A tanulmány mindazonáltal inkább közelítő becslésnek tekinthető, mivel a modell a kereslet változására lineáris válaszokat feltételez a termelő-felhasználásban, továbbá kizárólag az EU-n belüli környezeti hatásokkal számol.

BIESBROEK munkatársaival (2017) Hollandiában, több mint 35 ezer fő részvételével készült, egészségügyi és étrendi jellemzőket tartalmazó panel adatait elemezték tanulmányukban. Kiemelik, hogy a szakirodalom akár 35\%-os ÜHG kibocsátás csökkentési potenciált tulajdonít az étrendi ajánlásokhoz való igazodásnak, bár ezek hipotetikus, teljes és azonnali változások esetére vonatkoznak. Ők azonban nem modellezett, hanem valódi, naplózáson és 
egészségügyi nyomonkövetésen alapuló adatbázis alapján jutottak arra a következtetésre, hogy az ajánlásoknak a legkevésbé és a leginkább megfelelő csoport (fogyasztási tercilis) között a vizsgált időszakban 4-9\%-al csökkent az élelmiszerfogyasztás által indukált ÜHG kibocsátás és 5-10\%-al a termőterület-igény. Meg kell jegyeznünk azonban, hogy az étrend minőségi megítélésének számszerűsítése jelentős tudományos kihívás, és az eredmények nagyban függnek a választott indikátortól. A korábbi eredményekkel összehasonlítható Healthy Diet Indicator (HDI) az energiabevitel arányában határoz meg pontszámokat (a WHO ajánlásaival megegyező módon), míg a Dietary Approaches to Stop Hypertension (DASH) tömegben mért fogyasztási kvantilisek alapján, tehát relatív módon. Ez utóbbi indikátorral mérve az ajánlásokhoz való igazodás enyhén növelte az ÜHG kibocsátást. Ugyanazon mintának az étrend minőségének szélső értékei (fogyasztók tercilisei) között HDI-vel mérve 150\%-os, míg DASH alapján már csak 50\%-os különbség figyelhetők meg.

PERIGNON és szerzőtársai (2016) hangsúlyozzák, hogy a hirtelen bekövetkező, gyökeres étrendi változások modellezése nem vezethet reális eredményre. A felméréseken alapuló kutatások felhasználhatják a fentebb említett étrendi indikátorokat, vagy a tényleges egészségügyi hatásokból származó információkat. Előbbi esetén az idézett szerzók is felhívják a figyelmet a választott indikátor eredményeket alapvetően befolyásoló természetére, utóbbi módszer kivitelezése viszont hosszú távú longitudinális vizsgálatokat igényel. Nem véletlen, hogy az általuk vizsgált 10 tanulmány közül csak háromban jelenik meg az egészségügyi hatás, és ebből kettő esetében csak rizikófaktorok számszerúsítése formájában. A tanulmányok alapján a szerzők igazoltnak látják az egészségesebb étrend magasabb ökohatékonyságát, bár megjegyzik, hogy egyes helyettesítések, például a halfogyasztás magasabb szintje növelhetik a környezeti hatásokat. Az étrendek fajlagos költségeit vizsgálva bemutatják, hogy az fenntarthatóbb étrendi variációk feltételez- hetően magasabb élelmiszercélú kiadásokkal párosulnak. Véleményünk szerint ez a statikus elemzés azonban nem helytálló: a makroszinten átalakuló étrend megváltoztatja a piaci viszonyokat (kereslet - kínálat) hosszú távon tehát a mai élelmiszerárak nem mérvadók.

Az étrend környezeti hatásairól a fogyasztóknak meglehetősen kevés ismeretük van, feltehetően a kapcsolat közvetett jellege miatt. Egy Hollandiában és az Amerikai Egyesült Államokban végzett felmérés szerint ezt a környezetterhelést az előbbi ország állampolgárainak 12, míg az amerikaiak 6 százaléka ismeri fel (DE BOER et al., 2016). Ráadásul, még ha ezt az ismeretkört sikerülne is hatásosan bővíteni, a kívánt étrend kialakulása minden bizonnyal hosszadalmas és nehézkes lesz, hiszen az étrend nem csak fiziológiai és gazdasági tényezők által meghatározott, hanem igen nagymértékben függ kulturális tényezőktől. Egyes különösen fontos elemei, például a húsfogyasztás nagyon sok társadalomban státuszszimbólumnak tekinthetők, az étrend meglehetősen stabil, beágyazott jellemzője mind az egyénnek, mind a társadalomnak (MACDIARMID et al., 2016).

Célravezető lehet az étrendi változások pozitív környezeti és egészségügyi hatásainak nem különálló hangsúlyozása, hanem a közöttük fennálló szinergia mentén kialakított politika kialakítása (DE BOER et al., 2018), ennek teljes információs, jogi és gazdasági eszköztárával. LAZZARINI társaival (2016) svájci kísérletükben az egészségügyi és környezeti előnyök fogyasztók általi erős összekötését találták, ráadásul a vélt kapcsolat meghaladta az objektív, igazolható összefüggések mértékét. DE BOER és munkatársai (2016) az ún. spillover effect jelenlétét is megalapozottnak vélik, ez alapján célszerü a "könnyebb" környezetvédelmi cselekvések kialakítása és stabilizálása, majd erre alapozva ösztönözni a fogyasztókat a nagyobb lemondással járó életmód felé történő elmozdulásra. Előbbire példa lehet az energiatakarékos berendezések és a szelektív hulladékgyüjtés, utóbbiak közé tartozik a mobilitás és az étrend is. 


\section{KöVETKEZTETÉSEK - ConClusions}

A hazai és nemzetközi irodalmak alapján egyértelmúen látszik, hogy az élelmiszerfogyasztás, az egészség és a környezet kérdéseinél egyre kevésbé találkozhatunk csak az egyik vagy a másik területet vizsgáló irodalommal. A tanulmánnyal az volt a célunk, hogy egy átfogóbb képet adjunk eme három terület szoros kapcsolatáról és egymásra utaltságáról.

Az egészség és élelmiszerfogyasztás közötti szoros összefüggés már évtizedek óta ismert és jelentős tudományos, valamint közéleti téma, de a környezettudatosságot a fenntarthatóságon belül jellemzően izolált kutatásokkal vizsgálták korábban, nem a fogyasztói magatartás aspektusaiból. Ezen kapcsolat felismerése azonban megerősödni látszik, ahogy ez ki is derült a fent említett tanulmányokból. Az élelmiszerágazat felelőssége a környezetterhelés kapcsán is bizonyított, ennek hatására fellendülőben vannak azon új technológiák és étrendek, melyek támogatják a tudatosabb termelést és életvitelt.

A vállalati szféra és a politikai döntéshozók részéről látszanak az erőfeszítések, melyek az egészségesebb és a környezettudatosabb élelmiszer-ellátási lánc irányába mutatnak, de mivel legtöbbjük költség- és profit-vezérelt, így a megfelelő fogyasztói nyomás hatására érhető el globális változás. Ehhez a tudatossághoz elsősorban az ökológiai és az egészséggel kapcsolatos tudás megerősítése elengedhetetlen.

\section{KöSZÖNETNYILVÁNÍTÁS -}

\section{ACKNOWLEDGEMENT}

A kutatás a „Az élelmiszer-fogyasztás természeti erőforrás-igénye a társadalmi metabolizmus szempontjából” címú projekt keretében, a Nemzeti Kutatási, Fejlesztési és Innovációs Hivatal - NKFIH (K-115851) támogatásával valósult meg. A publikáció elkészítését az EFOP-3.6.1-16-2016-00022 számú, Debrecen Venture Catapult Program projekt támogatta. A projekt az Európai Unió támogatásával, az Európai Szociális Alap társfinanszírozásával valósult meg.

\section{IRODALOMJEGYÉK- REFERENCES}

Ádány, R.: Megelőző orvostan és népegészségtan. Medicina Könyvkiadó Zrt., Budapest, 2011.

Ágfalvi, R.: Iskola-egészségügyi kézikönyv. Medicina Könyvkiadó, Budapest, 1987.

Antal, M. - Péter, Sz.: Táplálkozás és légszennyezés. Egészségtudomány. 2016. 60 (1) $47-56$.

Bachmann, J. L. - Phelan, S. - Wing, R. R. - Raynor, H. A.: Eating Frequency is Higher in Weight loss Maintainers and Normal-Weight Individulas than in Overweight Indiviuals. Journal American Dietetic Association. 2011. 111 (11) 1730-1734. https://doi.org/ 10.1016/j. jada.2011.08.006.

Banerjee, B. - McKeage, K.: How Green is My Value: Exploring the Relationship Between Environmentalism and Materialism. Advances in Consumer Research. 1994. 21 (1) 147-152.

Barabás, K.: Az egészségfejlesztés Alapismeretek pedagógusoknak. Medicina Kiadó, Budapest, 2006.

Baum, R. - Gatchel, A. - Krantz, D.: Introduction to Health Psychology. London, McGraw Hill Inc., 1997.

Bazan, G.: Review: Our Ecological Footprint: Reducing Human Impact on the Earth. Electronic Green Journal. 1997. 1 (7)

Bentley, M.: An Ecological Public Health Approach to Understanding the Relationships Between Sustainable Urban Environments, Public Health and Social Equity. Health Promotion International. 2013. 29 (3) 528-537. https://doi. org/10.1093/heapro/dato28

Berners-Lee, M. - Hoolohan, C. Cammack, H. - Hewitt, C. N.: The Relative Greenhouse Gas Impacts of Realistic Dietary Choices. Energy Policy. 2012. (43) 184-190. https://doi. org/10.1016/j.enpol.2011.12.054 
Biesbroek, S. - Verschuren, W. M. M. -Boer, J. M. A. - van de Kamp, M. E. van der Schouw, Y. T. - Geelen, A. Looman, M. - Temme, E. H. M.: Does a Better Adherence to Dietary Guidelines Reduce Mortality Risk and Environmental Impact in the Dutch Sub-Cohort of the European Prospective Investigation into Cancer and Nutrition? British Journal of Nutrition. 2017. (118) 69-80. https://doi. org/10.1017/Sooo7114517001878.

Brávácz, I.: Az egészség- és környezettudatosság, mint új befolyásoló tényező az élelmiszerfogyasztói magatartásban. In: Fejlődő jogrendszer és gazdasági környezet a változó társadalomban (Szerk.: Karlovitz, J. T.). International Research Institute s.r.o., Komárno. 2015. 310-316.

Bush, M.: Sustainablility and Smile. Advertising Age. 2008. 79 (8) 1-25.

CDC: One Health. 2017. https://www.cdc.gov/ onehealth/index.html (Letöltés dátuma: 2017. április 1.)

Csete,M.: Regionáliséskörnyezetgazdaságtan. Edutus Főiskola, Budapest, 2012.

Darmon, N. - Drewnowski, A.: Does Social Class Predict Diet Quality? American Journal of Clinical Nutrition. 2008. 87 (5) 1107-1117.

Daróczi, E.: A várható élettartam Magyarországon európai összehasonlításban. In: Halálozási viszonyok az ezredfordulón: társadalmi és földrajzi választóvonalak (Szerk.: Daróczi, E. - Kovács, K.). NKI Kutatási Jelentések 77. Budapest, KSH, NKI. 2004. 41-74.

De Boer, J. - Aiking, H.: Prospects for Pro-Environmental Protein Consumption in Europe: Cultural, Culinary, Economic and Psychological Factors. Appetite. 2018. (121) 29-40. https://doi.org/10.1016/j. appet.2017.10.042

De Boer, J. - de Witt, A. - Aiking, H.: Help the Climate, Change Your Diet: A Cross-Sectional Study on How to Involve Consumers in a Transition to a Low-Carbon Society. Appetite. 2016. (98) 19-27. https://doi.org/10.1016/j. appet.2015.12.001.
Dombi, M.: A környezeti hatások értékelésének lehetősége ökoszisztémaszolgáltatások alapján. Tér és Társadalom. 2012. $26 \quad$ (2) 40-56. https://doi. org/10.17649/TET.26.2.2038

Dörnyei, K. R. - Gyulavári, T. Hofmeister-Tóth, Á. - Jenes, B. Jentetics, K. - Neumann-Bódi, E. Neulinger, Á. - Simon, J. - Zsótér, B.: Marketing az egészségtudatosságért - a marketing pozitív szerepe az egészségtudatosságtól a termékválasztásig. In: Tomcsányi Pál akadémikus 90 éves: $\mathrm{Az}$ életminőség anyagi és szellemi igényeinek kielégítése fogyasztási marketing szemlélettel (Szerk.: Lehota, J. - Berács, J. - Rekettye, G.). Felolvasó ülés és tanulmánykötet. Budapest: MTA Agrárközgazdasági Bizottság Agrármarketing Albizottság. 2014. 65-91.

Egészségtudományi

(ni.): Egészségtudatos magar https: / / fogalomtar a o k hu/index. php/Eg\%C3\%A9szs\%C3\%A9gtudatos_ magatart\%C3\%A1s (Letöltés dátuma: 2019. április 1.)

Élelmiszerfeldolgozók

Szövetsége (ÉFOSZ): élelmiszeriparról (Émóna http://www.efosz.hu/elelmiszeripar/azelelmiszeriparrol/ (Letöltés dátuma: 2017. április 2.)

FAOSTAT: Food Balance Sheets. http://www. fao.org/faostat/en/\#data/FBS (Letöltés: 2018. november 11.)

Farsang, A.: Talajvédelem. Pannon Egyetem Környezetmérnöki Intézet, Veszprém, 2011.

Füge, K. - Makai, A. - Breitenbach, Z. - Figler, M.: A testtömegindex és az egészséges táplálkozáshoz kapcsolódó attitűdök - Egy reprezentatív felmérés első eredményei. Új Diéta. 2015. 24 (4) 2-4.

Füzesi,Zs. - Varga, J.: Egészség-és betegségkoncepciók. In: Emberi folyamatok idegi szabályozása - a neurontól a viselkedésig (Szerk.: Ábrahám, H. - Ács, P. - Vörös, V. et al.). Pécsi Tudományegyetem, Dialóg Campus Kiadó-Nordex Kft., Pécs, 2014. 1206-1224. 
Gaál, Sz. - Szigeti, P. - Dimitra, P. - Matthew, G. - Ewout van, G.: Major Challenges Ahead for Hungarian Healthcare. British Medical Journal. 2011. 343. https://doi.org/10.1136/bmj.d7657

GFK: Növekszik az egészségtudatosság Magyarországon. 2012. http://www. gfk.hu/pressreleases/press_releases/ articles/010199/index.hu.html (Letöltés dátuma: 2012. november 20.)

GFK: Növekszik az egészségesnek tartott élelmiszerkategóriák fogyasztása. 2016a. http://www.gfk.com/hu/insightok/pressrelease/gfk-novekszik-az-egeszsegesnektartott-elelmiszerkategoriak-fogyasztasa/ (Letöltés dátuma: 2016. október 10.)

GFK: Trenddé alakulni látszik az egészségtudatosság. 2016b. http:// www.gfk.com/hu/insightok/pressrelease/gfk-trendde-alakulni-latszik-azegeszsegtudatossag/ (Letöltés dátuma: 2017. január 10.)

Grossmann, M.: On the Concept of Health Capital and the Demand for Health. Journal of Political Economy. (1972) 80 223-255. https://doi.org/10.1086/259880

Harmath, P.: Az egészség-magatartás néhány szociálpszichológiai és szociológiai kérdése. Orvosi Hetilap. 1978. 119 (9) 519522.

Harris, D. M. - Guten, S.: Health Protecting Behaviour: An Exploratory Study. Journal of Health and Social Behaviour. 1979. 20 17-29. https://doi.org/10.2307/2136475

Haytko, D. L. - Matulich, E.: Green Advertising and Environmentally Responsible Consumer Behaviors: Linkages Examined. Journal of Management and Marketing Research, 2008. 12-11.

Henter, I. - Mramurácz, É. - Szabó, Zs.: Táplálkozástani és élelmezési ismeretek. Líceum Kiadó, Eger, 2013. 7-22.

Hertwich, E. G.: The Life Cycle Environmental Impacts of Consumption. Economic Systems Research. 2011. 23 27-47. https://doi.org/10.1080/0953531 4.2010.536905
Hinterberger, F. - Giljum, S. - Hammer, M.: Material Flow Accounting and Analysis (MFA). A Valuable Tool for Analyses of Social-Nature Interrelationships. Internet Encyclopedia of Ecological Economics. 2003. http://ecoeco.org/pdf/material.pdf (Letöltés dátuma: 2015. március 2.)

Hofmeister-Tóth, Á. - Kelemen, K. Piskóti, M.: A fenntartható fogyasztás jellemzői és trendjei Magyarországon és a régióban. In: Fenntartható fogyasztás? A fenntartható fogyasztás gazdasági kérdései (Szerk.: Csutora, M. - Hofmeister-Tóth, Á.). AULA Kiadó, Budapest, 2011. 53-76.

Horváth, Á.: Élelmiszercímkék és az egészségtudatos fogyasztói magatartás. Marketing \& Menedzsment. 1997. (6) 5356

Huszka, P. - Süle, E.: Egészséges életmód kontra alkoholfogyasztás, - egy empirikus kutatás eredménye a bécsi (WU1) és a győri (SZE2) egyetemen II. In: Marketing megújulás: Marketing Oktatók Klubja 20. Konferenciája tanulmány kötet. (Szerk.: Hetesi, E. - Révész, B.). Szeged, Magyarország, 2014. 08.27.-2014.08.29. SZTE GTK. 448-457.

Johnston, J. L. - Fanzo, J. C. - Cogill, B.: Understanding Sustainable Diets: A Descriptive Analysis of the Determinants and Processes That Influence Diets and Their Impact on Health, Food Security, and Environmental Sustainability. Advances in Nutrition. 2014. 5 418-429. https://doi. org/10.3945/an.113.005553

Kerekes, S.: Boldogság, környezetvédelem és piacgazdaság. In: Fenntartható fogyasztás? A fenntartható fogyasztás gazdasági kérdései (Szerk.: Csutora, M. Hofmeister-Tóth, Á.). Budapesti Corvinus Egyetem, Budapest, 2011. 4-10.

Kerk Van de, G. - Manuel, A.: A Comprehensive Index for a Sustainable Society: The SSI - the Sustainable Society Index. Ecological Economics. 2008. 66 228-242. https://doi.org/10.1016/j. ecolecon.2008.01.029 
Kiss, V. Á.: A fenntarthatóbb fogyasztói magatartás és megnyilvánulási formái. TAYLOR Gazdálkodás- és szervezéstudományi folyóirat. 2015. 7 (34) (20-21) 313-324.

Kiss, V. Á. - Szakály, Z.: A fiatalok egészségtudatossága a táplálkozási szokásaikat illetően. In: Marketing hálózaton innen és túl, Az Egyesület a Marketing Oktatásért és Kutatásért XXI. országos konferenciájának tanulmánykötete (Szerk. Budapesti Müszaki és Gazdaságtudományi Egyetem Menedzsment és Vállalatgazdaságtan Tanszék) Konferencia helye, ideje: Budapest, Magyarország, 2015.08.272015.08.28. Budapest: Budapesti Müszaki Egyetem, 2015. 145-154.

Kiss-Tamás, L.: A modern egészségszemlélet alakulása.Abiomedikális, asalutogenetikus és napjaink egészségfejlesztő szemlélete. Budapest, Kompánia Füzetek, 2005. 5-20.

Kocsis, T.: „Hajózni muszáj!” A GDP, az ökológiai lábnyom és a szubjektív jóllét stratégiai összefüggései. Közgazdasági Szemle. 2010. 57 (június) 536-554.

Kopp, M. - Skrabski, Á. - Szedmák, S.: A testi és lelki egészség összefüggései országos reprezentatív felmérések alapján. Demográfia. 1999. 42 (1-2) 88-119.

Kotakorpi, E. - Lahteenoja, S. Lettenmeier, M.: Household MIPS Natural Resource Consumption of Finnish Households and its Reduction. Finland: Ministry of the Environment, Helsinki, 2008. 160.

Kozmáné, G.: Táplálkozás. 2015. http:// slideplayer.hu/slide/2144243/ (Letöltés dátuma: 2016. december 28.)

Könyves, E. - Vargáné Csobán, K.: Gasztronómia és turizmus. Elméleti jegyzet, Debreceni Egyetem, Debrecen, 2015.

Központi Statisztikai Hivatal (KSH): Magyarország 2013. KSH, Budapest, 2014b. 199.

Központi Statisztikai Hivatal (KSH): Élelmiszermérlegek és tápanyagfogyasztás, 2013. Statisztikai tükör. 2015a. (41) 1-5.
Központi Statisztikai Hivatal (KSH): Európai lakossági egészségfelmérés, 2014. Statisztikai Tükör. 2015b. (29) 9.

Központi Statisztikai Hivatal (KSH): $\mathrm{Az}$ ipari termelés volumenindexe alágak szerint (2001-2016). 2017a. https:// www.ksh.hu/docs/hun/xstadat/xstadat eves/i_oiaoo8a.html, (Letöltés dátuma: 2017. augusztus 19.)

Központi Statisztikai Hivatal (KSH): Magyarország 2016. KSH, Budapest, 2017b. 227.

Központi Statisztikai Hivatal (KSH): Egészségi állapot és egészségmagatartás, 2016-2017. Statisztikai Tükör, KSH, Budapest, 2018. 1-5.

Kriston, P. - Pikó, B.: Serdülőkorú fiatalok rizikómagatartásának elemzése önminősített egészségi állapotukkal összefüggésben. Népegészségügy. 2016. 94 (1) $22-32$.

Kuznetsova, D.: Healthy places: Councils leading on public health. London: New Local Government Network. 2012. http:// www.nlgn.org.uk/public/wp-content/ uploads/Healthy-Places_FINAL.pdf (Letöltés dátuma: 2014. november 5.)

Laczkó, M.: A rossz magyar egészségi állapot lehetséges magyarázó tényezői; összehasonlító makroelemzés magyar és osztrák adatok alapján, 1960-2004. IEHAS Discussion Papers, No. MT-DP - Institute of Economics, Hungarian Academy of Sciences. 2010. (7) 60.

Láng, I. - Csete, L. - Harnos, Zs.: A magyar mezőgazdaság agrárökológiai potenciálja az ezredfordulón. Mezőgazdasági Kiadó, Budapest, 1983.

Láng, I.: A környezetvédelem nemzetközi körképe. Mezőgazdasági Kiadó, Budapest, 1980.

Lazzarini, G. A. - Zimmermann, J. Visschers, V. H. M. - Siegrist, M.: Does Environmental Friendliness Equal Healthiness? Swiss Consumers' Perception of Protein Products. Appetite. 2016. 105 663-673. https://doi.org/10.1016/j. appet.2016.06.038

Lehota, J.: Élelmiszergazdasági marketing. Műszaki Kiadó, Budapest, 2001. 10157. 
Leip, A. - Billen, G. - Garnier, J. Grizzetti, B. - Lassaletta, L. - Reis, S. - Simpson, D. - Sutton, M. A. - de Vries, W. - Weiss, F. - Westhoek, H.: Impacts of European Livestock Production: Nitrogen, Sulphur, Phosphorus and Greenhouse Gas Emissions, Land-Use, Water Eutrophication and Biodiversity. Environmental Research Letters. 2015. 10. https://doi.org/10.1088/17489326/10/11/115004

Lucas, M. - Rohn, H. - Lettenmeier, M. - Liedtke, Ch. - Wiesen, K.: The Nutritional Footprint - Integrated Methodology Using Environmental and Health Indicators to Indicate Potential for Absolute Reduction of Natural Resource Use in the Field of Food And Nutrition. Journal of Cleaner Production. 2016. 20 161-170. https://doi.org/ 10.1016/j. jclepro.2015.02.070

Macdiarmid, J. - Kyle, J. - Horgan, G. W. - Loe, J. - Fyfe, C. - Johnstone, A. - McNeill, J.: Sustainable Diets For The Future: Can We Contribute to Reducing Greenhouse Gas Emissions by Eating a Healthy Diet? The American Journal of Clinical Nutrition. 2011. 92 632-639. https://doi.org/10.3945/ajen.112.038729

Macdiarmid, J. I. - Douglas, F. Campbell, J.: Eating Like There's No Tomorrow: Public Awareness of the Environmental Impact of Food and Reluctance to Eat Less Meat as Part of a Sustainable Diet. In: Appetite. 2016. 96 487-493. https://doi.org/10.1016/j. appet.2015.10.011.

Magyar Dietetikusok Országos Szövetsége: OKOSTÁNYÉR - Új magyar táplálkozási ajánlás. 2016. http://mdosz. $\mathrm{hu} / \mathrm{uj}$-taplalkozasi-ajanlasok-okostanyer/ (Letöltés dátuma: 2016. október 18.)

Magyar Távközlési Iroda (MTI): Győrffy Balázs: az élelmiszeripar a harmadik legnagyobb ipari ágazat Magyarországon. 2017. http://archiv1988tol.mti.hu/Pages/ HirSearch.aspx?Pmd=1 (Letöltés dátuma: 2017. szeptember 5.)
Majláth, M.: A pszichográfiai tényezők különbségei a környezetbarát és nem környezetbarát fogyasztók között. Doktori értekezés, Budapesti Corvinus Egyetem, Budapest, 2009.

Mancini, L. - Lettenmeier, M. - Rohn, H. - Liedtke, C.: Application of the MIPS Method for Assessing the Sustainability of Production-Consumption System of Food. Journal of Economic Behavior and Organization. 2012. 81 779-793. https:// doi.org/10.1016/j.jebo.2010.12.023

Marjainé, Sz. Zs. - Zsóka, Á. - Széchy, A.: Környezettudatosak-e a középiskolások? Fenntartható fogyasztás? Trendek és lehetőségek Magyarországon (Szerk.: Kerekes, S. - Csutora, M.). Aula Kiadó, Budapest, 2012. 225-258.

Masset, G. - Vieux, F. - Verger, E. O. - Soler, L. - Touazi, D. - Darmon, N.: Reducing Energy Intake and Energy Density for a Sustainable Diet: A Study Based on Self-Selected Diets in French Adults. The American Journal of Clinical Nutrition. 2014. 99 1460-1469. https:// doi.org/10.3945/ajen.113.077958

Matarazzo, J. D.: Behavioural Health: 1990 Challenge for the Health Sciences Professions. In: Behavioural Health: A Handbook of Health Enchancement and Disease Prevention. (Eds.: Matarazzo, J. D. et al.). John Wiley \& Sons Inc. New York, 1984. 3-40.

McGinnis, J. M. - Williams-Russo, P. - Knickman, J. R.: The Case for More Active Policy Attention to Health Promotion. Health Affairs. 2002. 21 (2-March) 78-93. https://doi. org/10.1377/hlthaff.21.2.78

Meffert, H. - Kirchgeorg, M.: Grundlagen des Umweltschutzes aus wettbewerbsstrategischer Persapektive Hausmann. Marktorientiertes Umweltmanagement, Verlag Gabler GmbH, Wiesbaden, 1994. https://doi. org/10.1007/978-3-322-85905-1_3

Morgan, G.: WHO Should Redefine Health? Journal of Epidemiology \& Community Health. 2009. 63 419. https://doi. org/10.1136/jech.2008.084731. 
Nagy, Sz.: Fenntartható fogyasztás. Nemzeti Tankönyvkiadó, Budapest, 2011.

Neira, M. - Gore, F. - Brune, M-N. - Hudson, T. - Garbino de, J. P.: Environmental Threats to Children's Health - A Global Problem. International Journal of Environment and Health. 2008. 2 (3-4) 276-292. https://doi.org/10.1504/ IJEnvH.2008.020922

Nemcsicsné Zsóka, Á.: Következetesség és rések a környezettudatos szervezeti magatartásban. Doktori (PhD) értekezés, Budapesti Corvinus Egyetem, Budapest, 2005.

Németh, T. - Várallyay, Gy.: A természeti erőforrások fenntarthatósága: mi van, ha nincs? Gazdálkodás. 2015. 59 (3) 201-219.

OECD: Obesity update 2017. 16. https://www. oecd.org/els/health-systems/ObesityUpdate-2017.pdf (Letöltés dátuma: 2018. szeptember 5.)

OECD/EU: Health at a Glance: Europe 2016 - State of Health in the EU Cycle, OECD Publishing, Paris, 2016. https://doi. org/10.1787/9789264265592-en

Perignon, M. - Vieux, F. - Soler, L. Masset, G. - Darmon, M.: Improving Diet Sustainability Through Evaluation of Food Choices: Review of Epidemiological Studies on the Environmental Impact of Diets. Nutrition Reviews. 2016. 75 (1) 2-17. https://doi.org/10.1093/nutrit/ nuw043

Pikó, B.: Egyenlőtlenségek az egészségi állapotban. Századvég. 1998. (11) 94-108.

Pikó, B. - Bak, J.: A gyermekek egészségés környezettudatosságának alakítása. Iskolakultúra. 2005. (5) 54-60.

Rabinowitz, P. M. - Kock, R. - Kachani, M. - Kunkel, R. - Thomas, J. et al.: Toward Proof to Concept of a One Health Approach to Disease Prediction and Control. Emerging Infectious Diseases. 2013. 19 (12) https://doi.org/10.3201/ eid1912.130265

Rigó, J.: Dietetika. Medicina Könyvkiadó, Budapest, 2002.
Röpke, I.: The Early History of Modern Ecological Economics from the Late 1980's to the Early 2000's. Ecological Economics. 2004. 55 (2) 262-290. https://doi. org/10.1016/j.ecolecon.2004.02.012

Ruini, L. F. - Ciati, R. - Pratesi, C.A. - Marino, M. - Principato, L. Vannuzzi, E.: Working Toward Healthy and Sustainable Diets: The "Double Pyramid Model” Developed by the Barilla Center for Food and Nutrition to Raise Awareness about the Environmental and Nutritional Impact of Foods. Frontiers in Nutrition. 2015. 2 (9) https://doi. org/10.3389/fnut.2015.00009

Schäfferné Dudás, K.: A környezettudatosság többszintű értelmezése és a környezettudatos fogyasztói magatartás. Doktori értekezés, Pécsi Tudományegyetem Közgazdaságtudományi Kar Gazdálkodástani Doktori Iskola, Pécs, 2008.

Sloan, A. E.: The Top Ten Functional Food Trends. Food Technology. 2014. 68 (4) 1-10.

Szita-Tóth, K. - Tóth, L. - Szekeres, Zs. - Szúts, L. - Galbács, Z. - Fenyvessy, J.: Shopping, Cooking and Eating, Hungary. Final Report. Delft University of Technology, Delft, 2000.

Szabó, S.: Egészségorientált táplálkozási szokások és a fogyasztói magatartás kapcsolata. Doktori értekezés, Kaposvári Egyetem Gazdaságtudományi Kar, Kaposvár, 2016.

Szakály, Z.: Hagyományos magyar termékek piaci lehetőségeinek elemzése. Élelmiszer, Táplálkozás és Marketing. 2008. 5 (2-3) 57-65.

Szakály, Z.: Táplálkozásmarketing. Mezőgazda Kiadó, Budapest, 2011.

Szakály, Z. - Pető, K. - Popp, J. Jasák, H.: A fenntartható fogyasztás iránt elkötelezett fogyasztói csoport, a LOHAS szegmens jellemzői. Táplálkozásmarketing. 2015. 2 (1) 3-9. https://doi.org/10.20494/TM/2/1/1 
Szlávik, J.: Lépések a fenntartható gazdálkodás irányába: Gondolatok Láng István és Kerekes Sándor Megalakult a Túlélés Szellemi Kör című vitairatához. Magyar Tudomány. 2014 (1) 99-108.

Tarry-Adkins, J. L. - Ozanne, S. E.: Nutrition in Early Life and AgeAssociated Diseases. Ageing Res. Rev. 2017. 96-105. https://doi.org/10.1016/j. arr.2016.08.003

Teisl, M. F.: Environmental Concerns in Food Consumption. In: The Oxford Handbook of the Economics of Food Consumption and Policy. (Eds.: Lusk, J. L. - Roosen, J. - Shogren, J. F.). Oxford, 2011. 26. https://doi.org/10.1093/ oxfordhb/9780199569441.013.0035

Tomesányi, P.: Az életmód-gazdaságtan alapvonásai. Magyar Tudomány. 2011. (1) 94-104.

Tompa, A.: A daganatos betegségek előfordulása, a hazai és nemzetközi helyzet ismertetése. Magyar Tudomány. 2011. (11) 1333-1345.

Töröcsik, M.: Az ételfogyasztás megatrend kapcsolódásai. Táplálkozásmarketing. 2014. 1 (1-2) 19-27. https://doi. org/10.20494/TM/1/1-2/2

Törőcsik, M.: Életstílust kifejező ételfogyasztás, a food-trendek hatása. Korunk. 2010. 21 (12) 58-65.

Tudatos Vásárlók Egyesülete (TVE): Tudatos Vásárló Piaci Jelentés. 2017. https://issuu.com/tudatosvasarlok/docs/ tudatos_vasarlo_piaci_jelentes (Letöltés dátuma: 2017. október 22.)

Tukker, A. - Goldboom, R. A. - de Koning, A. - Verheijden, E. - Kleijn, R. - Wolf, O. - Pérez-Domínguez, I. Rueda-Cantuche, J. M.: Environmental Impacts of Changes to Healthier Diets in Europe. Ecological Economics. 2011. 70 1776-1780. https://doi.org/10.1016/j. ecolecon.2011.05.001

Urbán, R.: Az egészségkárosító viselkedések klinikai és egészségpszichológiai megközelítése. In: Egészségpszichológia a gyakorlatban (Szerk.: Kállai, J. et al.). Medicina, Budapest, 2014. 279-303.
Uzzoli, A.: A budapesti 14-19 év közötti korosztály életkörülményeinek vizsgálata esettanulmányok alapján. Tér és Társadalom. 2000. 14 (2-3) 229-237. https://doi.org/10.17649/TET.14.2-3.590

Várallyay, Gy.: $\quad A \quad$ talaj multifunkcionalitásának szerepe a jövő fenntartható mezőgazdaságában. Acta Agronomia Hungarica 50 éves jubileumi különszám. 2002. 13-25.

Vetőné Mózner, Zs.: Az élelmiszerfogyasztás környezeti hatásai és szerkezeti változásai. In: Fenntartható fejlődés, élhető régió, élhető települési táj 2. (Szerk.: Marjainé Szerényi, Zs. - Podruzsik, Sz.). Budapesti Corvinus Egyetem, Budapest, 2012. 29-43.

Vetter, S. H. - Sapkota, T. B. - Hillier, J. - Stirling, C. M. - Macdiarmid, J. I. - Aleksandrowicz, L. - Green, R. - Joy, E. J. M. - Dangour, A. D. - Smith, P.: Greenhouse Gas Emissions from Agricultural Food Production or Supply Indian Diets: Implications for Climate Change Mitigation. Agriculture, Ecosystems \& Environment. 2017. 237 (16) 234-241. https://doi.org/10.1016/j. agee.2016.12.024

Vitrai, J. - Vokó, Z.: Egészségmodell. In: Népegészségügyi Jelentés (szakértőknek). Johan Béla Országos Epidemiológiai Központ, Budapest, 2006.

Wackernagel, M. - Rees, W.: Our Ecological Footprint: Reducing Human Impact on the Earth. New Publishers, Gabriola Island, 1996.

Westhoek, H. - Lesschen, J. P. - Rood, T. - Wagner, S. - De Marco, A. Murphy-Bokern, A. - Leip, A. van grinsven, H. - Sutton, M. A. - Oenema, O.: Food Choices, Health and Environment: Effects of Cutting Europe's Meat Meat and Dairy Intake. Global Environmental Change. 2014. 26 196-205. https://doi.org/10.1016/j. gloenvcha.2014.02.004

WHO (2015): Noncommunicable disease. http://www.who.int/mediacentre/ factsheets/fs355/en/, letöltés dátuma: 2016. december 12. 
Wilkinson, R. G. - Pickett, K. E.: Income Inequality and Social Dysfunction. Annual Review of Sociology. 2009. 35 493511. https://doi.org/10.1146/annurevsoc-070308-115926

Xu, X. - Lan, Y.: A Comparative Study on Carbon Footprints Between Plan- and Animal-Based Foods in China. Journal of Cleaner Production. 2016. 112 (4) 2581-2592. https://doi.org/10.1016/j. jclepro.2015.10.059
Zsolnai, L.: Ökológia, gazdaság, etika. Helikon Kiadó Kft., Budapest, 2001.

\section{JEGYZETEK $\nRightarrow$ NOTES}


JEGYZETEK $\nRightarrow$ NOTES 